\title{
Strontium-90 transport parameters from source term to aquifer in the Chernobyl Pilot Site
}

\author{
D.A. Bugai, L. Dewiere', V.A. Kashparov ${ }^{2}$ and N. Ahamdach ${ }^{1}$ \\ Institute of Geological Sciences, Gonchara Str. 55-b, Kiev 01054, Ukraine \\ ${ }^{1}$ Institute for Nuclear Safety and Protection, BP. 6, 92266 Fontenay-aux-Roses cedex, France \\ ${ }^{2}$ Ukrainian Institute of Agricultural Radiology, Mashinostroiteley Str. 7, Chabany, \\ Kiev Region 255205, Ukraine
}

\begin{abstract}
Results are presented from multidisciplinary radiological and hydrogeological studies of process and parametcrs controlling ${ }^{90} \mathrm{Sr}$ releases from the shallow trench containing nuclear fuel particles and subsequent radionuclide transport in the undertying eolian and alluvial sand aquifer at Chemobyl Pilot Site located at $2.5 \mathrm{~km}$ distance from the Cbemobyl NPP. Microscopic analyses of fuel particles separated from waste have identified two families of particles: $\mathrm{U}-\mathrm{O}$ and $\mathrm{Zr}-\mathrm{U}-\mathrm{O}(-25 \%$ and $75 \%$ of the fuel particles respectively). The $\mathrm{Zr}-\mathrm{containing}$ particles exhibits low dissolution rate, therefore radionuclide inventory in source term available for migration is significantly less than estimated before. The ${ }^{90} \mathrm{Sr}$ migration velocity in the eolian sand layer is estimated at $\approx 7 \%$ of real groundwater flow velocity $\left(K_{\infty} \neq 3 \mathrm{mi} / \mathrm{g}\right.$ ). Alluvial sediments comprising the middle part of the aquifer have notably higher sorption capacity $\left(K_{-} \approx 20 \mathrm{ml} / \mathrm{g}\right)$, and may represent essential natural sorption barrier to geo-migation. Radioactivity balance calculations show that $4-7 \%$ of initial trench inventory of ${ }^{90} \mathrm{Sr}$ has migrated by now to the geological environment. Presented results have important implications on safery assessment and remedial analyses of the radioactive waste dumps at ChNPP.
\end{abstract}

\section{INTRODUCTION}

The waste dumpsites created in 1986-87 during emergency clean-up activities at Chernobyl Nuclear Power Plant (ChNPP) do not satisfy regulatory requirements to engineered low-level waste near-surface disposal facilities and pose radiological risks to the environment. Of particular concem is hydrogeologic migration of strontium-90 $\left({ }^{90} \mathrm{Sr}\right)$, which shows high mobility in soils and groundwater system [1].

Below we report results of multidisciplinary radiological and of hydrogeological studies of process controlling ${ }^{90} \mathrm{Sr}$ releases from the shallow trench containing nuclear fuel particles and subsequent radionuclide transport in the underlying sandy aquifer at Chemobyl Pilot Site (Fig.1). Microscopic characterization of fuel particles provided insight into physical and chemical properties and dissolution mechanisms of Chernobyl fallout, which determines radioactivity of the source term. Using in-situ radiometric measurements geometry and inventory of radioactivity within the trench was estimated. Based on site geology characterization and hydrogeology monitoring data conceptual model of geomigration process was established. Obtained data allowed us to estimate in-sin ${ }^{90} \mathrm{Sr}$ retardation in the subsurface, and integral ${ }^{90} \mathrm{Sr}$-leaching rate from radioactive waste burial to ground water system. Field estimates of radionuclide transport parameters are crosschecked by independent experimental methods. Characterization studies provide data and parameters and have important implications to safety assessment and remedial analyses of the radioactive waste dumps at ChNPP.

\section{SITE DESCRIPTION}

The study site is located 2.5 kilometers south west of the ChNPP in the so-called "Red Forest" radioactive waste dumpsite. In 1987 in the course of clean-up works radioactive materials, made of topsoil layer and contaminated tree trunks from the dead pines "red forest" killed by extreme radiation levels in 1986, have been bulldozed in-situ in a few meters deep trenches [1].

A particular waste burial (trench no.22-T), namely Chernobyl Pilot Site (CPS), was selected since 1998 for radiological characterization and monitoring studies reported below. The burial represents $-70 \mathrm{~m}$ long, 8-10 $\mathrm{m}$ wide and 2-2.5 $\mathrm{m}$ deep unlined trench (see Fig.1). The source term of radionuclide migration to the environment is a heterogeneous mixture of contaminated organic materials and soil 
containing micron-size reactor fuel particles. The specific activity of ${ }^{137} \mathrm{Cs}$ and ${ }^{90} \mathrm{Sr}$ in waste is $10^{5}$ $10^{6} \mathrm{~Bq} / \mathrm{kg}$.

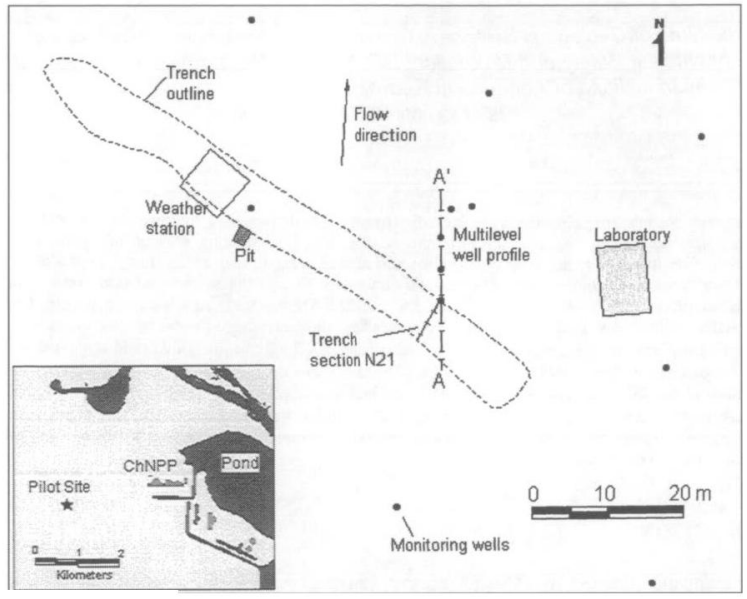

Figure 1. Map of the Chemobyl Pilot Site

The geologic section of CPS consists of the sequence of sedimentary layers of Quatemary eolian and alluvial sands with beds of sandy loam material. The depth to groundwater table is $1-3 \mathrm{~m}$. The unconfined sandy aquifer is bounded at a depth of $30 \mathrm{~m}$ by a low permeable Eocene marl layer. Average annual rainfall is $550-650 \mathrm{~mm}$, while infiltration recharge rate to aquifer is estimated at $150-250 \mathrm{~mm} . \mathrm{y}^{-1}$. For 14 years following disposal, radionuclides have been leached from the trench by meteoric water, and have been penetrating the underlying unsaturated soil and the aquifer. As a result, ${ }^{90} \mathrm{Sr}$ concentration in groundwater in the upper part of the aquifer in the vicinity of the trench varies between $n \times 100$ and $n \times 10,000 \mathrm{~Bq} / 1$, and the radiostrontium plume has spread some $10 \mathrm{~m}$ downstream from the source $[2,3]$.

\section{SOURCE TERM CHARACTERIZATION}

\subsection{Microscopic characterization of nuclear fuel particles}

Chernobyl fall-out radionuclides were initially associated with micron-size dispersed nuclear fuel "hot particles" $[4,5]$. In order to quantify the source term of migration, it is necessary to determine the physical and chemical characteristics of fuel particles and their dissolution rates.

Scanning Electron Microscopy (SEM) was applied for visualization, determination of size, geometry, and chemical composition of particles separated from the CPS waste. The methodology is described in [6]. In total 568 hot particles (mean diameter of $4.2 \mu \mathrm{m}$ ) were separated from trench material by sedimentation in heavy liquid (bromoform). Based on estimation of activity of waste before and after fuel particle separation, it was estimated that by year 2000 , about $70 \%$ of ${ }^{90} \mathrm{Sr}$ activity in trench is associated with fuel particles. The most important finding is that source term consists of two types of fuel particles: 1) composed of uranium $(\mathrm{U})$ and oxygen $(\mathrm{O})$, and 2) composed of $\mathrm{U}, \mathrm{O}$ and zirconium $(\mathrm{Zr})$. U-O-Zr 
particles account for $75 \%$ of the source term. SEM showed that U-O particles have significant secondary porosity due to chemical weathering, while $\mathrm{Zr}-\mathrm{U}-\mathrm{O}$ particles demonstrated much higher stability. The Chernobyl fallout dissolution models developed before [4] considered that the source term is only U-O particles. However, according to new data in case of CPS significant portion of activity in the trench will likely remained "bound" to $\mathrm{Zr}-\mathrm{U}-\mathrm{O}$ particles and therefore unavailable for migration process for long time.

\subsection{Inventory of radioactivity within the waste site}

Back in 1987 in difficult radiological conditions creation of trench no.22-T by civil defense troops has not been accurately documented. To characterize distribution and inventory of radioactivity within the trench the following methodology was developed. Bore holes were drilled on a mesh through the trench body, and in-situ measurement of $\gamma$ - emission profiles in boreholes were done using submersible counting probe. Next specific activity of ${ }^{137} \mathrm{Cs}$ in soil was estimated using empirical correlation equation (Fig.2-a) between radionuclide content in soil $\left(\mathrm{A}_{\mathrm{Cs} . \mathrm{i}}, \mathrm{Bq} / \mathrm{kg}\right)$ and $\gamma$ - count rate $(\mathrm{N}$, number of counts per 10 seconds):

$$
\mathrm{A}_{\mathrm{Cs}, \mathrm{i}}=\Gamma \times \mathrm{N}, \quad \Gamma=2.5 \pm 1 \mathrm{~Bq}(\mathrm{~kg} \text { count })^{-1} .
$$

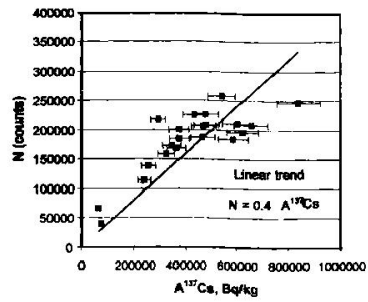

(a)

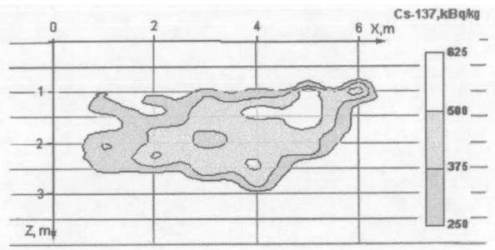

(b)

Figure 2. Estimation of ${ }^{137} \mathrm{Cs}$ distribution in trench. (a) - Empirical relation for estimation of ${ }^{i 37} \mathrm{Cs}$ activity in waste from number of $\gamma$-counts; (b) - Derived ${ }^{137} \mathrm{Cs}$ distribution in trench cross-section N21 (see Fig. 1 for cross-section location).

Example distribution of ${ }^{137} \mathrm{Cs}$ activity in trench cross-section is shown at Fig.2-b. Spatial integration of about 2000 individual activity measurements in bore holes results in the following integral estimate of ${ }^{137} \mathrm{Cs}$ activity in the trench (for 2000):

$$
A_{C s}=600 \pm 240 \mathrm{GBq} \text {. }
$$

Inventory of other fission products was estimated using empirical "correlation" radionuclide activity ratios for trench material and for Chernobyl fuel particles [5]. Direct correlation between ${ }^{90} \mathrm{Sr}$ and ${ }^{137} \mathrm{Cs}$ activity in trench is relatively poor, because ${ }^{90} \mathrm{Sr}$ has been re-distributed inside and outside the trench due to hydrologic migration process. Therefore two-step approach was developed. First ${ }^{154} \mathrm{Eu}$ content in trench was estimated using experimental ratio of activity ${ }^{137} \mathrm{Cs} /{ }^{154} \mathrm{Eu}$ for the waste at CPS $\left(\mathrm{R}_{\mathrm{Cs}-\mathrm{Eu}}{ }^{\mathrm{TR}}=145\right.$ for 2000):

$$
\mathrm{A}_{\mathrm{Eu}}=\mathrm{A}_{\mathrm{Cs}} / \mathrm{R}_{\mathrm{Cs}-\mathrm{Eu}}{ }^{\mathrm{TR}}=4 \pm 1.6 \mathrm{GBq} \text {. }
$$

Europium is relatively immobile radionuclide, which was associated mainly with the fuel matrix. Therefore good correlation exists between ${ }^{90} \mathrm{Sr}$ and ${ }^{154} \mathrm{Eu}$ activity in Chernobyl reactor fuel particles $\left(\mathrm{R}_{\mathrm{Sr}-\mathrm{Eu}}{ }^{\mathrm{FP}}=72\right.$ for 2000 ) [5]. This allows estimating initial ${ }^{90} \mathrm{Sr}$ activity inventory within the trench (without account for outside migration):

$$
\mathrm{Asr}_{\mathrm{Sr}}=\mathrm{R}_{\mathrm{Sr}-\mathrm{Eu}} \mathrm{FP} \times \mathrm{A}_{\mathrm{Eu}}=290+140 \mathrm{GBq} \text {. }
$$

In reality, experimentally determined ${ }^{90} \mathrm{Sr} /{ }^{154} \mathrm{Eu}$ activity ratio for the trench waste material is $\mathrm{R}_{\mathrm{Sr} \text {-Eu }}{ }^{\mathrm{TR}}=67$ (for 2000 ), indicating that the trench is on average depleted in ${ }^{90} \mathrm{Sr}$. The above data allows us to estimate amount of radiostrontium, which has migrated outside the trench: 


$$
\Delta S r=\frac{R_{S r-E w}^{F P}-R_{S r-E w}^{T R}}{R_{S r-E S}^{F P}} 100 \%=7 \pm 5 \% .
$$

\section{SITE GEOLOGY STRUCTURE AND HYDRODISPERSION PARAMETRS}

Geology structure of CPS was characterized from series of 8-9 m deep boreholes, and core material was subjected to grain size analyses. The derived data were compared to characteristic grain size distribution "fingerprints" of the different genetic types of continental sediment facies [2]. As result, the following main packs of sediments of different genetic origin and lythological properties were distinguished within the geologic profile of the CPS (from top to bottom; see Fig.4): artificial "man caused" sediment layer, disturbed by clean-up operations ( 114.6-114 m a.s.l.); cover facies of eolian suite ( 114-109.5 m a.s.l.); alluvial sediments of the overbank-dead channel facies (109.5-104 $\mathrm{m}$ a.s.l.). The characteristic grain-size distribution curves of eolian and alluvial sediments are presented at Fig.3. Eolian sediment pack is relatively homogenous and has low content of clay fraction. On the contrary alluvial sediments have remarkably higher content of fine particles and are rather heterogeneous, representing sequence of subhorizontal layers of varying grain size composition and thickness. The major sand mineral constituents are quartz (80-90\%) and feldspar (10-20\%) [3].

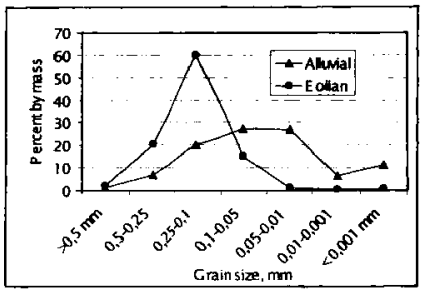

Figure 3. Cumulative grain-size distribution curves for eolian and alluvial sediments.

Hydraulic properties of sediments at CPS were estimated by several alternative techniques including field hydraulic tests (slug and pump-tests on wells), laboratory column experiments, and inverse modeling [2]. From these studies hydraulic conductivity of eolian sands is estimated at $K_{\text {col }}=3-5 \mathrm{~m} /$ day. The alluvial sediment pack appears to be anisotropic with on average much lower permeability in vertical direction (z): $\mathrm{K}_{\mathrm{al}, \mathrm{x}} \approx 1 \mathrm{~m} / \mathrm{day}, \mathrm{K}_{\mathrm{al},} \approx 0.02-0.05 \mathrm{~m} /$ day.

To characterize hydrogeology regime the detailed piezometer network in three dimensions was installed at the CPS (Fig.1, 4). Based on observations of hydraulic head distribution in the aquifer, the flow regime in eolian and alluvial layers appears to be essentially different. In eolian layer the groundwater flows mainly horizontally with average hydraulic head gradient of $0.001-0.002$. In lower permeability alluvial sediment pack flow is nearly vertical with by order of magnitude higher head gradient of 0.02-0.04 (Fig.4).

The preliminary indirect estimates of groundwater flow direction and velocity were confirmed in the course of natural gradient tracer test in eolian sand layer conducted at a scale of $-1 \mathrm{~m}$ using injection of ${ }^{36} \mathrm{Cl}$ [2]. From this test groundwater flow occurs approximately to the North (see Fig.1), while real groundwater velocity was estimated at $\sim 3 \mathrm{~cm} /$ day.

Analysis of spatial distribution of sediment permeability allowed us to get first estimates of solute transport parameters. The variographic analysis and some stochastic modeling show that for conservative tracer the longitudinal dispersivity should be in the range of $8 \mathrm{~mm}$ to $6 \mathrm{~cm}$. A larger scale tracer test in natural flow conditions started at CPS in August 2001 will serve as an experimental validation test. 


\section{STRONTIUM-90 DISTRIBUTION AND RETARDATION IN THE AQUIFER}

${ }^{9} \mathrm{Sr}$ distribution in the subsurface was characterized using series of multilevel wells installed to the aquifer along the groundwater flow direction, as determined from the tracer test. In addition, the ceramic vacuum samplers were installed to unsaturated zone to sample moisture in inside the trench (see Fig.4).

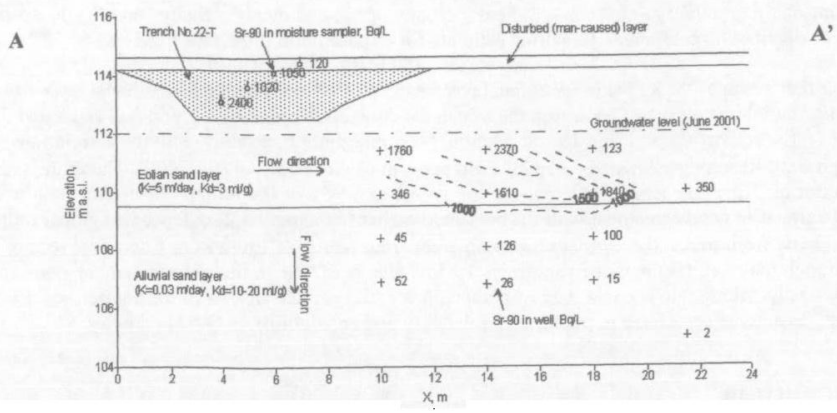

Fyure 4. ${ }^{90} \mathrm{Sr}$ distribution in cross-section of the aquifer at CPS in June (analytical error 10-20\%).

The ${ }^{90} \mathrm{Sr}$ plume in the aquifer with concentrations of $\sim 1000-2000 \mathrm{~Bq} / \mathrm{L}$ (i.e., similar to porous solutions inside the trench) extends from the trench approximately $10 \mathrm{~m}$ downstream. Background activity in the top part of the aquifer of an order of $n \times 100 \mathrm{~Bq} / \mathrm{L}$ is due to vertical migration in unsaturated zone from the "man-caused" layer containing residual contamination. In accordance with groundwater flow pattern, radionuclide plume is slightly "dipping" with distance from the trench, being displaced from top by more "clean" infiltration recharge water. The downstream edge of the plume reaches interface zone between eolian and alluvial layers. Here dissolved ${ }^{90} \mathrm{Sr}$ encounters alluvial sediments with much higher sorption and retardation potential due to large content of clay fraction (see Fig.3).

Assuming that the derived in the course tracer experiment estimate of groundwater flow velocity (i.e., $\sim 11 \mathrm{~m} /$ year) is representative in the 14 years retrospective, ${ }^{90} \mathrm{Sr}$ migration velocity in the eolian layer can be estimated at $\sim 7 \%$ of groundwater velocity, and relevant retardation factor is $R \approx 14$. The "back-calculated" from $R$ strontium sorption distribution coefficient $\left(\mathrm{K}_{d}\right)$ value for colian sands is $2.7 \mathrm{ml} / \mathrm{g}$.

In addition to indirect estimations, ${ }^{90} \mathrm{Sr} \mathrm{K}_{\mathrm{d}}$ values were studied in laboratory batch experiments, and in special in-situ "water-sediment" radioactivity partition tests. The methodology of batch experiments is described in [7]. Groundwater from CPS was used as a test solution (Table 1). For the purpose of in-situ $\mathrm{K}_{\mathrm{d}}$ determinations, sediment cores were extracted from the water saturated top part of eolian layer, and porous solution was immediately separated from matrix by applying vacuum. Next, ${ }^{90} \mathrm{Sr}$ activity was separately determined for liquid and solid phase, and $K_{d}$ values were estimated using straightforward calculations. Results are presented in Table 2 . Distribution coefficient values for eolian layer by different methods are in good agreement $(\sim 2-3 \mathrm{mV} / \mathrm{g})$. Estimated $\mathrm{K}_{\mathbf{d}}-\mathrm{s}$ for alluvial sediments are $\sim 10$ times higher.

Table 1. Chemical composition of groundwater from CPS used as test solution in laboratory batch ${ }^{90} \mathrm{Sr} \mathrm{K}_{\mathrm{d}}$ studies (mgl).

\begin{tabular}{|c|c|c|c|c|c|c|c|c|c|c|}
\hline $\mathrm{Ca}$ & $\mathrm{K}$ & $\mathrm{Mg}$ & $\mathrm{Na}$ & $\mathrm{Fe}$ & $\mathrm{Cl}$ & $\mathrm{SO}_{4}$ & $\mathrm{NO}_{3}$ & $\mathrm{HCO}_{3}$ & $\mathrm{TDS}$ & $\mathrm{PH}$ \\
\hline 25 & $\mathbf{8 . 6}$ & 1.2 & 1.4 & 0.1 & 2.5 & 27.2 & 61.1 & 12.2 & 140 & 5.85 \\
\hline
\end{tabular}

Table 2. Average and range (in parentheses) of ${ }^{x 0} \mathrm{Sr} \mathrm{K}_{\mathrm{d}}$ values determined by different methods ( $\mathrm{m} \mathrm{V}_{\mathrm{g}}$ ).

\begin{tabular}{|l|c|c|c|}
\hline Genetic sediment type & In-situ plume retardation & Batch experiments & $\begin{array}{c}\text { In-situ "water-sediment" } \\
\text { partition tests }\end{array}$ \\
\hline Eolian sands & 2.7 & 2.8 & $2.0(0.2-5)$ \\
\hline Alluvial sediments & No data & $20(6-50)$ & No data \\
\hline
\end{tabular}


The data on ${ }^{90} \mathrm{Sr}$ distribution in groundwater and derived $\mathrm{K}_{d}$ estimates allow evaluating radionuclide inventory in the aquifer. Amount of ${ }^{90} \mathrm{Sr}$ (both dissolved in groundwater and adsorbed on sediments) was calculated via spatial integration:

$$
A_{A Q}=\iint C(x, z)\left(m+\rho K_{d}\right) d x d z
$$

where $A_{A Q}$ is ${ }^{90} \mathrm{Sr}$ inventory in the aquifer ( $\mathrm{Bq}$ per $1 \mathrm{~m}$ of trench cross-section), $C(\mathrm{x}, \mathrm{z})$ is ${ }^{90} \mathrm{Sr}$ concentration in groundwater, $m$ is sediment porosity, $\rho$ is sediments density, and $K_{d}$ is spatially dependent distribution coefficient. Resulting estimate for cross-section A-A' (see Fig. 1 ) is:

$$
A_{A Q}=200-350 \mathrm{MBq} \text {, }
$$

assuming that average ${ }^{90} \mathrm{Sr} \mathrm{K}_{\mathrm{d}}$ value for eolian layer ranges from 2 to $3 \mathrm{ml} / \mathrm{g}$, and for alluvial layer from 10 to $20 \mathrm{ml} / \mathrm{g}$. Initial inventory of ${ }^{90} \mathrm{Sr}$ within the trench for the considered cross-section was estimated using data on ${ }^{137} \mathrm{Cs}$ activity in soil for trench section $\mathrm{N} 21$ and fission product activity correlations (see paragraph 3.2). Resulting estimate is $5.5+2.2 \mathrm{GBq}$ per $1 \mathrm{~m}$ of cross-section (for 2000). Therefore, present day amount of ${ }^{90} \mathrm{Sr}$ in the aquifer in cross-section is $\sim 4$ to $6.5 \%$ of the initial ${ }^{90} \mathrm{Sr}$ inventory in trench. The last value is in good agreement with the presented earlier (paragraph 3.2) independent global estimate of ${ }^{90} \mathrm{Sr}$ release from trench (i.e., $7 \pm 5 \%$ ) based on comparing ${ }^{90} \mathrm{Sr}$ to ${ }^{154} \mathrm{Eu}$ ratio in Chemobyl reactor fucl and in trench material. (Estimate of paragraph 3.2 includes both ${ }^{90} \mathrm{Sr}$ in the unsaturated zone and in the aquifer). Lastly, taking into account data of paragraph 3.1, the amount of ${ }^{90} \mathrm{Sr}$ in the aquifer is $\sim 12-23 \%$ of initial ${ }^{90} \mathrm{Sr}$ activity associated in trench with relatively higher solubility $\mathrm{U}-\mathrm{O}$ fuel particles.

\section{CONCLUSIONS}

Presented above results have important implications to safety assessment and remedial analyses of the radioactive waste dumps at ChNPP. Due to the fact that significant portion of radioactivity in the trench is associated with relatively stable $\mathrm{Zr}-\mathrm{U}-\mathrm{O}$ particles, inventory of activity potentially available for migration in dissolved and ion-exchangeable forms should be decreased, while phenomenological waste leach rate coefficients have to be proportionally increased. On the counter part, some residual contamination will stay in topsoil layer for longer period. Therefore previous risk assessment analyses (e.g., [8]) need to be revised and updated. Uncertainties in future risk assessment studies can be reduced accounting for sitespecific radiological and hydrogeological data and parameter estimates derived in this study. In particular, alluvial sediment layer composing middle part of the unconfined aquifer at Chernobyl site may represent essential natural sorption barrier to radionuclides migration from waste dumps via groundwater pathway.

\section{Acknowledgments}

The authors are grateful to C. Grenier (CEA/MTMS/RT) for the stochastic analysis of permeability data, and to S.Zvarich (UIAR) for the laboratory determination of ${ }^{90} \mathrm{Sr} \mathrm{K}_{d}-\mathrm{s}$.

\section{References}

[1] Dzhepo S.P. et al., Geol.Zhurn. 1994-4/6 (1994) 100-108 (in Russian).

[2] Bugai D.A. et al., "Study of radionuclide migration in geological environment at experimental polygon Pilot Site in the area of near-surface disposal of radioactive wastes in the near zone of ChNPP". Water Exchange and Chernobyl Accident. V. Shestopalov Ed. (Ukrainian National Academy of Sciences, Kiev, 2000), pp.346-383 (in Russian).

[3] Bugai D.A. et al., Ecological Chemistry, 14 (1995) 273-278.

[4] Kashparov V.A. et al, Health Phys., 76 (1999) 251-259.

[5] Kuriny V.D. et al., Ann. Nucl.Energy, 20 (1993) 415-420.

[6] Ahamdach N. and Stammose D., CRAS, 330 (2000), 415-422.

[7] Patterson J.R. and Spoel T., Water Resour.Res., 17 (1981) 513-520.

[8] Bugai D.A. et al. Health Phys., 71 (1996) 9-18. 